\title{
EMBLEMAS DO DESPOJAMENTO NA POESIA DE H. KOLODY
}

\author{
(Infinito presente, Curitiba, 1980)
}

As comentar o último livro de Helena Kolody, (Tempo, 1970), vimos na captação da instantaneidade a estrutura formal básica da apreensão poética; agora aparece Infinito presente, nova obra onde se acentua, já a partir do título, a dimensão temporal como for. ma característica e dominante da cosmovisão kolodyana. Do tempoinstante ao tempo-eternidade ("O tempo é mar que se alarga/num infinito presente"), o livro de 1980 marca a continuidade ascenciente da perspectiva vital, espirital e artística de $\mathrm{H}$. Kolody.

No mesmo comentário citava-se o poema Penumbra como clave emblemática e premonitória do estadio espiritual que o livro integro marcava na trajetória criativa da autora:

Já se aprofundam as raizes

no repouso do silêncio.

Cresce o musgo nas fundas cicatrizes.

Levita a fronde.

Na penumbra dos ramos,

tímido pássaro

inicia um canto de eternidade.

Da mesma, maneira, Infinito presente possui seu poema emblemático (cf. a etimologia do termo emblema: "o tudo está numa só coisa", e sua significação pelo Diccionario de términos filológicos, de Carreter: "desenho simbólico com uma legenda em forma de sentença") prefiguração do livro e autodefinição da atitude espiritual que representa, no itinerário do aprofundamento poético: é ultimo, que inclusive inspira a composição visual da capa:

Vôo solitário

na fimbria da noite

em busca do pouso distante.

\section{(Ultimo)}

Aproximando ambos poemas-clave, é surpreendente notar que eles se correspondem, a dez anos de distância objetivação figurativa e na alusão que o símbolo refere: o "tímido 
pássaro" sustentado pela fronde levitante, que iniciava em Penumtra o canto de eternidade, levanta agora o vôo e ganha a altura veriginosa donde pode apreender em abstrata visão circular o Cosmos e sua Humanidade. Aqui o símbolo não é mera função estetizante, mas torna-se o "profundo abısmo de intuição estelar, vértice mais alto da criação artística, e ao mesmo tempo seu veio mais subterrâneo", no dizer de Baruzzi. E o aludido processo de reiteração simbólica, puramente intuitivo, junguianamente espontâneo, só vem reafirmar a gênese exemplar das Imagens interiores da autora, isto é, a autenticidade sempre renovada de seu ser poético.

A fase do vôo: assim pode qualificar-se este alargamento ascendente do eu lírico, que deixando para trás as imagens sensitivas do mundo, torna-se o descifrador de correspondências nas "florestas de símbolos" baudelairianas, que compõem nosso universo perceptível, tal qual os kolodyanos olhos que "verão além do aparente/em dımensão diferente" (Nova dimensão). Este é o "itinerário do conhecer", o desvendamento que sua palavra traz, num ato de inocencia, acentuadamente nos últimos poemas do livro, provando que uma oculta ordem orienta a sucessividade total da obra.

E o poeta chega à visão; o poeta vidente vê o humano viver, 'fagulha' sorvida pela eternidade:

Fagulhas dentro da noite resplandecem um momento e logo desaparecem.

Partindo, como o filósofo, do eu em introspeção, "porto" seguro, pois dos outros nunca conhece os "ignorados subterrâneos" ("Parte do porto / do próprio ser / o itinerário / do conhecer"), à inspeção do Ser detém-se nos lampejos de inexplicáveis estados de alma, "lacunas invisíveis" do eu, (Lacuna), nas sensações sutís, só música ("O rio sonoro invade as veias"). Vê a morte, parca, panteira emboscada ou jaguar no rasto da presa, abismo ou libertação para aquele vôo definitivo do "mergulho na verdade", estranhamente semelhante as que é dado ao poeta em vida ("E só a morte nos liberta").

Ve, das cidades humanas, a concreção de cimento, mas desvenda-lhes a circulação invisivel de mar abstrato, surrealista alegoria de algas e peixes de sonho, como no poema Interferência, que lembra 0 interseccionismo de alguns poemas pessoanos: 
Um mar abstrato circula

sua alegoria de algas,

seus claros peixes oníricos

no rígido aglomerado

de cortiços verticais.

O poeta visionário toma consciência, de seu fazer poético, e em evolução paralela à do místico, conclui no fascínio vertiginoso do silêncio:

Espelho do intransitivo

sòmente o silêncio

reflete $o$ indizível

(Elogio do silêncio).

Mas é a experiência da dor a marca necessária da suprema vidência:

O sofrimento burila

a própria argila pensante

muda a maneira de ser.

A "dor de aprender" atinge nesta obra, a fase pungente da abstração, pois todo acesso à verdade é para o poeta, transe de dor; apaga-se o mundo exterior e pela dor se faz a descoberta da luz no âmago do Absoluto,

Nada retém as mãos de cinza

do que avidamente guardavam.

Dissolve-se na treva

a imagem do espelho.

Permanece a chama

luz integrada na luz

num infinito presente

(Cinza e chama).

Sob o fundo incolor desta pureza mental, o poeta vidente não tarda em descobrir a luz abstrata, tão intensa agora, "no interior da morada", que "nem palidece as estrelas":

O bilho da lâmpada no interior da morada

empalidece as estrelas.

(Luz interior).

Mas como se inscreve toda esta ascese vital, transmutada em 
matéria poética, na face estilística da obra? Utilizando aquele verbo descarnado e denso que em Tempo já remetia à essencialidade do silêncio, o despojamento aqui se faz de sensação à abstração. Abolido o descritivo, anulado o mundo exterior, que os sentidos e as sensações reconhecem e sondam, o mundo da natureza, surge c estilo da abstração simbólica: tudo vale pelo desciframento, como no poema Evolução,

Caem as folhas de repente brotam outras pelos ramos murcham flores, surgem pomos e a planta volta à semente.

Assim somos. Sutilmente diferimos do que fomos.

tudo remete ao transcendente, um transcender humanizado que pode integrar-se o "clarão de beleza" da graça adolescente, ou a "presença quase ausente" do extremo final da vida.

A técnica interseccionista, na captação de dois tempos simultâneos acima mencionada, é mais um procedimento pelo qual é operada a passagem da sensação à abstração:

Explode a vida numerosa,

a morte ceifa, o mal se atreve, brota o amor, irrompe a greve nesse intervalo passageiro em que na rua rumorosa muda de cor o sinaleiro.

(Pletora)

A poéticc do despojamento essencial na fase do vôo, na ascese espiritual e na técnica da expressão é fixada na emblemática solidão da ave, prenunciada ao anoitecer, na "fímbria da noite", quando se extinguem ao redor seres e objetos, solidão onde em vida "enoitecemos enluarados de ausência".

E o "pouso distante" do emblema? Nada é dito dele, envolto na impenetrabilidade do Mistério que "amedronta e fascina". Mas a faculdade intuitiva do poeta vidente também o projeta na gravitante simbolização do despojamento definitivo e total, a ponto de exprimir-se no vasto arquétipo místico da oposição sombra-luz: no poema precisamente intitulado "Luz e sombra". 


\section{Derrotadas}

terra e treva, reina a luz eternamente.

E ilícito ao crítico vaticinar sobre a imprevisível unicidade da criação? Não o será, entretanto, ao leitor atento que presente já o verbo transparente vindo Do pouso distante, nos futuros (e próximos, espera-se) versos de Helena Kolody. 